\title{
Statutory meetings in Geneva
}

\author{
(April 1989)
}

\section{- League Executive Council}

The Executive Council of the League of Red Cross and Red Crescent Societies held its 23rd session in Geneva on 20 and 21 April 1989, under the chairmanship of the League President, Mr. Mario Villarroel.

In his address, Mr. Villarroel expressed the hope that the League's 70th anniversary and the "Humanitarian Gesture" celebrated in May in connection with the Movement's 125th anniversary would encourage National Societies to continue building the Movement in the spirit that spurred those who founded it.

League Secretary General Mr. Pär Stenbäck then reported on the activities carried out by the Secretariat since October 1988, focusing on relief operations and National Society development.

The Council provisionally admitted the Dominica Red Cross as the federation's 148th member; it also examined a draft ICRC/League agreement to be used as a basis for discussion with the ICRC before being submitted to the League General Assembly and was given details on a worldwide campaign for the protection of war victims, involving the League, the ICRC and the National Societies (following a resolution adopted by the Council of Delegates in 1987).

Delegates attending the Executive Council were also given an oral report of the Commission on the League Strategy for the Nineties, stressing the need for a strategy better adapted to the present world situation.

The Council moreover noted the change in the title of the Museum in Geneva to "International Museum of the Red Cross and Red Crescent", to reflect more fully the Movement's composition. At its last session in October 1988, the Council had requested the League Secretary-General to take the necessary steps in this respect.

The Executive Council fixed the date of its next session on 20 October 1989, to be followed by the VIIth session of the League General Assembly on 21 October and from 23 to 26 October. The Council of Delegates will meet on 27 October 1989. 


\section{- Standing Commission of the Red Cross and Red Crescent}

The Commission met on 18 April and discussed various points of interest to the Movement, in particular the provisional agenda of the Council of Delegates in October 1989 and the list of observers to attend the meeting.

The Commission also decided that the Henry Dunant Medal would be awarded to the following persons:

- Mr. G. Elsey (USA);

- Dr. A. Fourati (Tunisia);

- Mr. G. Mencer (Czechoslovakia);

- Mr. K. Snidvongs (Thailand);

- Mr. L. G. Stubbings (Australia);

- Mr. M. Egabu (Uganda) (posthumous award).

The Commission also awarded for the first time the Red Cross and Red Crescent Prize for Peace and Humanity following the adoption of a resolution (No. 1) by the Council of Delegates in 1987. The prize is to be awarded to the Lebanese Red Cross.

The Henry Dunant Medal and the Red Cross and Red Crescent Prize for Peace and Humanity will both be awarded by the Chairman of the Standing Commission on 26 October next at the end of the opening session of the Council of Delegates.

An information session was held at the ICRC for the National Society delegates attending the Commission meeting.

\section{- League's 70th birthday}

The League recently celebrated the 70th anniversary of its foundation in Paris on 5 May 1919. The brainchild of American Red Cross leader Henry P. Davison, it had five founding members-the Red Cross Societies of France, Great Britain, Italy, Japan and the United States of America. On its foundation they declared: "We are confident that this Movement, assured as it is at the outset of the moral support of the international community, has in it "great possibilities of adding immeasurably to the happiness and welfare of mankind". Seven months later it numbered 23 member Societies.

A 30-page illustrated brochure relating the highlights of the League's history has been published in English, French, Arabic and Spanish (See also p. 266). 